JKKP : Jurnal Kesejahteraan Keluarga dan Pendidikan

http://doi.org/10.21009/JKKP

DOI: doi.org/10.21009/JKKP.062.03

E-ISSN : 2597-4521

\title{
TELUR ASIN SEHAT RENDAH LEMAK TINGGI PROTEIN DENGAN METODE PERENDAMAN JAHE DAN KAYU SECANG
}

\author{
Meddiati Fajri Putri ${ }^{1, a)}$ \\ a) Medatifp68 unnesstaff@yahoo.co.id \\ 1)Prodi PKK Jurusan PKK Fakultas Teknik, Universitas Negeri Semarang
}

\begin{abstract}
Abstrak
Tujuan dari pembuatan telur asin adalah sebagai upaya untuk pengawetan, selain itu juga untuk meningkatkan cita rasa dari telur. Pengasinan telur merupakan teknologi pengolahan hasil ternak yang sering digunakan untuk menjaga kualitas telur karena pembuatannya yang mudah dan ekonomis sehingga memiliki peminat yang cukup banyak. Masyarakat menggunakan telur bebek untuk proses pengasinan, karena telur bebek mempunyai pori - pori yang besar dan rasa amis, sehingga baik digunakan untuk telur asin. Waktu pengasinan sangat berpengaruh pada masa simpan telur semakin lama pengasinan semakin lama masa simpan telur. Tujuan penelitian ini untuk mengetahui kadar lemak dan kadar protein pada telur asin sehat rendah lemak. Metode pengasinan meliputi metode pengasinan basah dan metode kering. Pengasinan dengan metode kering dilakukan dengan penutupan kulit telur dengan 2 tumbukan batu bata dan garam dalam bentuk adonan pasta, pengasinan dengan metode perendaman dengan cara merendamkan telur dengan larutan garam. Metode yang digunakan perendaman jahe dan kayu secang, dilanjutkan dengan analisa kadar protein menggunakan metode semimikro kjeldhal dan analisa kadar lemak menggunakan metode ekstraksi menggunakan soxhlet. Total kadar lemak hasil penelitian yang terdapat dari telur asin setelah perlakuan mengalami penurunan sebanyak $0,34 \mathrm{~g}-0,25 \mathrm{~g}=0,09 \mathrm{gram}$ $(4,5 \%)$. Dan kadar protein pada telur asin hasil penelitian mengalami peningkatan dari $21,79 \%$ menjadi $26,25 \%$. Untuk itu dapat direkomendasikan bahwa telur asin hasil penelitian lebih sehat untuk dapat dikonsumsi ditinjau dari kadar lemak dan protein yang dihasilkan.
\end{abstract}

Kata Kunci: Telur asin sehat, Rendah Lemak, Tinggi Protein.

\section{HEALTHY LOW-FAT HIGH-PROTEIN SALTED EGGS LOW USING GINGER AND SAPPAN} SOAKING-METHOD

\begin{abstract}
Salted eggs are one of the products that people like. The principle of making salted eggs is the process of ionizing $\mathrm{NaCl}$ salts which then diffuses into the egg through the shell pores (Wulandari et al. 2014). The purpose of making salted eggs is as an effort to preserve, in addition to increasing the taste of eggs. Egg salting is a technology of processing livestock products which is often used to maintain egg quality because the manufacture is easy and economical so it has quite a lot of enthusiasts. The community uses duck eggs for the salting process, because duck eggs have large pores and fishy taste, so they are good for salted
\end{abstract}


eggs. The time of salting is very influential in the shelf life of the egg the longer the salting time the longer the shelf life of the egg. The purpose of this study was to determine the fat content and protein content of healthy low-fat salted eggs. The salting method includes the method of wet salting and the dry method. Salting with a dry method is done by closing the egg shell with 2 collisions of bricks and salt in the form of a paste dough, salting with immersion method by immersing the egg with a salt solution. The method used was soaking ginger and secang wood, followed by analysis of protein content using the semimicro kjeldhal method and fat content analysis using extraction methods using Soxhlet. The total fat content of the research results from salted eggs after treatment decreased by $0.34 \mathrm{~g}-0.25 \mathrm{~g}=0.09 \mathrm{grams}(4.5 \%)$. And the protein content in salted eggs increased from $21.79 \%$ to $26.25 \%$. For that reason, it can be recommended that the salted eggs from the research results be healthier to be consumed in terms of the levels of fat and protein produced.

Keywords : Salted eggs are healthy, low fat, high in protein.

\section{PENDAHULUAN}

Telur itik mempunyai kadar air lebih rendah, sedangkan kandungan protein dan lemak lebih tinggi (Winarno dan Koswara 2002). Kondisi ini menyebabkan telur itik sangat cocok untuk diolah menjadi telur asin. Sampai saat ini telur asin yang berasal dari telur itik belum bisa digantikan oleh telur yang dihasilkan unggas lain. Telur asin merupakan salah satu produk yang disukai masyarakat. Prinsip dari pembuatan telur asin adalah terjadinya proses ionisasi garam $\mathrm{NaCl}$ yang kemudian berdifusi ke dalam telur melalui pori-pori kerabang (Wulandari et al. 2014). Pengasinan telur merupakan teknologi pengolahan hasil ternak yang sering digunakan untuk menjaga kualitas telur karena pembuatannya yang mudah dan ekonomis sehingga memiliki peminat yang cukup banyak. Masyarakat menggunakan telur bebek untuk proses pengasinan, karena telur bebek mempunyai pori - pori yang besar dan rasa amis, sehingga baik digunakan untuk telur asin.

Konsumsi telur asin di perkotaan meningkat dari tahun ke tahun. Namun demikian, belakangan ini mulai muncul kesadaran akan tingginya kandungan kolesterol yang terdapat pada telur asin. Tingginya kolesterol pada telur asin menimbulkan sebuah keresahan dan juga peluang bagi pengusaha. Konsumen resah karena mereka ingin tetap mengkonsumsi telur asin namun khawatir akan bahaya kolesterol dan lemak yang terlalu tinggi. Bagi pengusaha keresahan ini bisa menjadi peluang untuk menghasilkan sebuah terobosan telur asin sehat rendah kolesterol tinggi protein.

Kayu secang yang bernama latin Caesalpinia Sappan $L$ merupakan salah satu jenis rempah-rempah yang dimanfaatkan kulit kayu dan batang kayunya, sebagai bahan rempah. Kulit dari kayu secang dapat mengeluarkan zat pewarna merah alami. Oleh karena itu, kayu secang sering sekali digunakan sebagai bahan dasar untuk pewarna, terutama warna merah. Hal ini disebabkan karena kulit kayu secang memiliki senyawa Brazilin, yang dapat menghasilkan warna alami merah. Manfaat kayu secang juga memiliki kandungan polifenol yang tinggi. Polifenol sendiri merupakan salah satu zat yang merupakan manfaat antioksidan dan penangkal radikal bebas, yang seperti terkandung pada manfaat teh hijau. Minyak atsiri merupakan salah satu jenis minyak essensial yang terkandung di dalam kayu secang. Sifatnya yang utama, adalah menimbulkan aroma yang khas dan unik.

Menurut Kikuzaki dan Nakatani (1993) jahe merupakan salah satu tanaman rempah yang dapat digunakan sebagai pengawet. Jahe memiliki zat antioksidan alamai karena pada jahe terdapat senyawa zingerone, shogaol, gingerol, gingerdiol, diarylheptanoid, dan kurkumin. Komponen bioaktif jahe juga bersifat anti mikroba. Adanya sifat antioksidan alami maupun bersifat anti mikroba pada jahe maka dapat digunakan sebagai pengawet alami. Aroma jahe dapat diserap kedalam telur karena pada jahe terdapat minyak atsiri yang menimbulkan aroma khas jahe, serta adanya gingerol dan shogaol untuk rasa pedas. 
Sukarne (2010) melaporkan bahwa selain mempunyai citarasa yang khas, telur asin herbal juga mempunyai kandungan kolesterol yang lebih rendah. Sehingga kekhawatiran sebagian masyarakat terhadap kandungan kolesterol yang tinggi pada telur asin bisa diminimalisasi.

Teknologi pembuatan telur asin dapat diperkaya dengan penambahan kayu secang dan jahe sebagai bahan pengawet alami, menekan kadar lemak dan kolesterol serta meningkatkan konsumsi kepada masyarakat, sehingga dapat menciptakan produk telur asin terbaru. Diharapkan dengan penambahan kayu secang dan rimpang jahe pada proses pembuatan telur asin dapat memperbaiki karakteristiknya. Dengan menciptakan produk olahan telur asin yang rendah kolesterol, diharapkan masyarakat tidak takut lagi mengkonsumsi telur asin. Mengingat kandungan telur itik yg lebih tinggi ketimbang telur ayam. Hal ini merupakan sebuah peluang yang layak dikembangkan dan sangat profitable untuk dijalankan.

\section{Telur Asin}

Telur asin adalah telur yang sebelumnya diolah dulu, proses pembuatannya membutuhkan kecermatan dan ketelitian tersendiri dari bahan baku telur menjadi telur asin yang benar-benar memiliki rasa yang khas.

Telur asin adalah salah satu bentuk pengawetan telur yang dapat ditemukan di beberapa negara, misalnya Indonesia, Cina dan Taiwan. Keuntungan dari proses pengasinan disamping pengawetan adalah meningkatkan cita rasa, yaitu masir atau berpasir yang didapatkan dari kuning telur. Telur yang biasa digunakan untuk pembuatan telur asin adalah telur itik. Hal ini adalah karena telur itik mempunyai kadar lemak yang lebih tinggi dibandingkan dengan telur ayam. Menurut Direktorat Gizi Departemen Kesehatan RI (1979) kadar lemak kuning telur itik adalah 35\%, sedangkan kadar lemak kuning telur ayam adalah $31.9 \%$. Proses pengasinan dapat dibedakan menjadi dua cara yaitu merendam telur dengan larutan garam jenuh dan membungkus telur dengan adonan garam yang biasanya terdiri dari bubukan bata, abu gosok dan garam atau dengan kata lain pemeraman (Suprapti, 2002).

Bahan-bahan yang diperlukan dalam pembuatan telur asin antara lain: untuk 100 butir telur bebek dibutuhkan $1 \mathrm{~kg}$ abu dapur, $1 \mathrm{~kg}$ batu merah yng sudah ditumbuk halus, 0,5 kg gram dapur yang sudah ditumbuk halus, 25 gram asam sendawa dan air secukupnya.

Cara pembuatan telur asin dimulai dari telur dicuci dengan air hangat kemudian dikeringkan, setelah itu campur menjadi satu garam dapur kristal, bubuk batu bata yang diaduk sampai homogen, tambahkan air sampai membentuk adonan kental, telur yang sudah dibersihkan bungkus satu persatu dengan adonan tersebut, taruh pada wadah tutup adonan sampai permukaan telur asin tertutup, kemudian dieramkan atau disimpan selama 7-14 hari. Setelah dieramkan cui telur asin tersebut bila akan direbus atau dipanggang.

Tabel 1. Kandungan gizi telur asin per 100 gram

\begin{tabular}{lr}
\hline Energi & $195 \mathrm{kal}$ \\
Protein & $13,6 \mathrm{~g}$ \\
Lemak & $13,6 \mathrm{~g}$ \\
Karbohidrat & $1,4 \mathrm{~g}$ \\
Kalsium & $120 \mathrm{mr}$ \\
Fosfor & $15 i$ \\
Zat besi & $2 \ldots . \ldots$ \\
Vitamin A & $841 \mathrm{IU}$ \\
Vitamin B1 & $0,28 \mathrm{mg}$ \\
\hline
\end{tabular}

Sumber : Kementrian Kesehatan RI

Keunggulan pembuatan telur asin dengan cara perendaman adalah prosesnya lebih singkat, sangat mudah dan praktis dilakukan, namun kualitas telur asin yang dihasilkan kurang baik (Astawan, 2008). Menurut Suprapti (2002) telur asin yang dibuat dengan metode perendaman dalam larutan garam jenuh akan memiliki putih telur yang berlubang-lubang (Keropos). Kesulitan teknis juga dapat terjadi dalam 
pembuatan telur asin dengan metode ini karena telur akan terapung dalam larutan garam (Margono dan Muljadi, 2000). Cara pembuatan telur asin dengan menggunakan adonan garam akan menghasilkan telur asin yang lebih bagus mutunya, warna lebih menarik serta memiliki cita rasa yang lebih enak, tetapi proses pembuatannya lebih rumit dan waktu yang diperlukan lebih lama. Selain itu terdapat pula kelemahan yang lain seperti penurunan berat dan pembesaran ukuran diameter kantung udara telur yang terjadi selama proses pengasinan. Berikut ini formasi Rinci Komposisi Kandungan Nutrisi/Gizi Pada Telur Asin/100gram:

\section{Kayu Secang}

Secang merupakan tanaman yang sudah lama banyak digunakan sebagai obat tradisional. Komponen antioksidan yang terdapat dalam kayu secang merupakan tanda bahwa bahan alam ini cukup baik digunakan sebagai sumber zat antioksidan.

Kayu secang merupakan sumber antioksidan alami. Sudah banyak penelitian tentang khasiat tanaman secang, baik sebagai antimikroba, antioksidan, maupun zat pewarna alami. Komponen senyawa bioaktif yang terkandung dalam kayu secang, yaitu brazilin, brazilein, 3'-O-metilbrazilin, sappanone, chalcone, sappancalchone, alkaloid, flavonoid, saponin, tanin, steroid, dan terpenoid dan komponen umum lainnya, seperti asam amino, karbohidrat dan asam palmitat yang jumlahnya relatif sangat kecil. Komponen brazilin merupakan spesifik dari kayu secang yang dapat memberikan warna merah kecoklatan jika teroksidasi atau dalam suasana basa. Selain itu, brazilin ini diduga juga dapat melindungi tubuh dari keracunan akibat radikal kimia. Hasil beberapa penelitian menunjukkan bahwa ekstrak kayu secang berpotensi sebagai antimikroba.

Penambahan kayu secang pada susu kedelai dapat dijadikan sebagai alternatif bahan peng alami, karena kayu secang tersebut mengandung senyawa antibakteri (phenol dan flavonoid) yang dapat membuat telur asin lebih awet serta kayu secang berkhasiat sebagai pengawet, antioksidan dan antibakteri sehingga dapat mengurangi bakteri dalam bahan pangan (Hariana, 2006). Rebusan ekstrak secang mengandung senyawa tanin yang berfungsi sebagai antibakteri dan astringen. Senyawa brazilin mempunyai aktivitas sebagai antibakteri dan bakterioostatik. Penelitian (Miksusanti et al., 2011) berkesimpulan bahwa kayu secang dapat menghambat aktivitas bakteri Bacillus cereus dengan kadar fenol 590,428 mg/gram. Menurut (Kumala et al., 2013) berkesimpulan bahwa rebusan kayu secang menghambat aktivitas bakteri Salmonella thypii dan Escherichia coli secara in vivo diduga yang berperan adalah tanin dan asam galat.

\section{Jahe}

Jahe (Zingiber officinale Rosc.) merupakan rempah-rempah Indonesia yang sangat penting dalam kehidupan sehari-hari, terutama dalam bidang kesehatan. Jahe merupakan tanaman obat berupa tumbuhan rumpun berbatang semu dan termasuk dalam suku temu-temuan (Zingiberaceae). Jahe banyak mengandung berbagai fitokimia dan fitonutrien. Beberapa zat yang terkandung dalam jahe adalah minyak atsiri $2-3 \%$, pati $20-60 \%$, oleoresin, damar, asam organik, asam malat, asam oksalat, gingerin, gingeron, minyak damar, flavonoid, polifenol, alkaloid, dan musilago. Minyak atsiri jahe mengandung zingiberol, linaloal, kavikol, dan geraniol. Rimpang jahe kering per 100 gram bagian yang dapat dimakan mengandung 10 gram air, 10-20 gram protein, 10 gram lemak, 40-60 gram karbohidrat, 2-10 gram serat, dan 6 gram abu. Rimpang keringnya mengandung 1-2\% gingerol (Suranto, 2004). Kandungan gingerol dipengaruhi oleh umur tanaman dan agroklimat tempat tumbuh tanaman jahe. Gingerol juga bersifat sebagai antioksidan sehingga jahe bermanfaat sebagai komponen bioaktif anti penuaan. Komponen bioaktif jahe dapat berfungsi melindungi lemak atau membran dari oksidasi, menghambat oksidasi kolesterol, dan meningkatkan kekebalan tubuh (Kurniawati, 2010). Hasil penelitian Kikuzaki dan Nakatani (1993) menyatakan bahwa oleoresin jahe yang mengandung gingerol memiliki antioksidan melebihi a tokoferol, sedangkan hasil penelitian Ahmed et al., (2000) menyatakan bahwa jahe memiliki daya antioksidan yang sama dengan vitamin $\mathrm{C}$. 


\section{Lemak dan Kolesterol Pada Telur Asin}

Kandungan lemak terdapat dalam semua bahan makanan dan minuman. Pada dasarnya, semua lemak itu baik karena lemak dibutuhkan untuk menjaga kelangsungan hidup manusia. Fungsi lemak dalam tubuh manusia, lemak dibagi menjadi dua kelompok yaitu: lemak struktural dan lemak fungsional. Lemak struktural adalah bagian dari dinding sel. Sedangkan, lemak fungsional dapat berupa hormon steroid, prostaglandin, dan timbunan lemak yang dapat dipakai sebagai cadangan energi. Pada dasarnya, lemak makanan (dietary fat) memiliki fungsi untuk menyediakan energi jangka panjang, memberikan rasa kenyang setelah makan, membantu pembuatan hormon, membentuk bagian otak dan sistem saraf, membentuk membran sel untuk setiap sel di dalam tubuh, mengangkut vitamin $A, D, E$, dan $K$ ke seluruh tubuh, membantu mengatur suhu tubuh, serta menyediakan dua asam lemak esensial (seperti asam linoleat dan asam linolenat) yang tidak bisa dibuat sendiri oleh tubuh manusia.

Berbagai penelitian menunjukkan hubungan erat antara jumlah konsumsi lemak dan timbulnya penyakit jantung koroner. Lemak jenuh dapat meningkatkan kejadian penyakit jantung koroner, sedangkan lemak tidak jenuh akan menurunkan kejadian penyakit jantung koroner. Lemak tidak jenuh terbagi menjadi lemak tidak jenuh tunggal (asam oleat) dan lemak tidak jenuh ganda.

Dalam pembuatan telur asin digunakan bahan-bahan tambahan seperti garam dapur, abu, batu bara, kayu secang dan jahe.

Tabel 2. Kandungan Gizi Telur Asin

\begin{tabular}{lr}
\hline \multicolumn{1}{c}{ Kandungan Telur Asin (100 gram) } & Jumlah \\
\hline Energi (kkal) & 183 \\
Protein (gram) & 12,7 \\
Lemak (gram) & 13,6 \\
Karbohidrat (gram) & 1,4 \\
Natrium (mg) & 529 \\
Kalsium (mg) & 120 \\
\hline
\end{tabular}

\section{Kolesterol}

Kandungan kolesterol telur bebek jauh lebih tinggi dari telur ayam, demi kebaikan sebaiknya mengkonsumsi dengan batasan. Setiap telur mengandung 619 miligram kolesterol, di mana dua kali lipat melebihi dari batasan asupan harian yang direkomendasikan. Dan batasan ini lebih dari tiga kali lipat bagi penderita masalah jantung dan kolesterol.

Beberapa penelitian memang menunjukkan jika kolesterol dari makanan tak akan berpengaruh banyak, namun mengkonsumsi apapun secara berlebihan tentu tak baik akibatnya. Kolesterol tinggi bisa berpengaruh negatif terhadap kesehatan, terlebih bagi penderita penyakit jantung atau yang kondisi terkait arteri. Beberapa penelitian menunjukkan bahwa kolesterol dari telur tidak berpengaruh banyak terhadap darah, namun walau bagaimanapun lebih baik mengkonsumsinya dalam jumlah yang tidak berlebihan. Hal ini terutama bagi orang yang sebelumnya diketahui memiliki kolesterol tinggi.

Menurut Kalpana Bhaskaran dari Nutrition Research and Head of Glycemic Index Research Unit di Temasek Polytechnic's School of Applied Science, makan telur asin bisa meningkatkan kadar kolesterol dalam tubuh, melebihi jumlah yang direkomendasikan setiap harinya yaitu $300 \mathrm{mg}$. Apalagi dalam sebutir telur asin bisa terkandung 300-600 mg kolesterol, tergantung dari proses pembuatannya.

\section{METODOLOGI PENELITIAN}


Materi yang digunakan dalam penelitian ini telur itik, garam, sodium nitrit, jahe , kayu secang, dan abu gosok. Telur itik sejumlah 10 butir yang tersedia, diperoleh dari penjual telur asin di Banaran Semarang yang berumur kurang dari 5 hari. Alat yang digunakan untuk penelitian meliputi ember plastik sedang, tempat telur (egg tray), pengaduk, pisau, blender, pH-meter, alat teropong telur (candler), timbangan digital,jangka sorong, mikrometer, gelas ukur, sabut dan alat tulis.

\section{Metode}

a. Seleksi Telur

Telur itik dipilih dari telur yang segar (umur telur kurang dari 5 hari) dengan bentuk normal (oval) dan warna relatif sama (hijau kebiruan). Selanjutnya telur dicuci hingga bersih sambil diamati kondisi kerabang (tidak retak). Telur yang telah bersih dan kerabang utuh selanjutnya dilakukan candling, yaitu pengamatan bagian dalam telur/internal untuk melihat kondisi dan keadaan internal.

b. Perendaman dengan larutan garam dan bata merah

Buat adonan garam dan bata merah dengan perbandingan 1:2, kemudian telur dipilih dan dicuci hingga bersih dan dibalut dengan adonan bata merah. Susun telur yang telah dibalut dalam ember selama 10 hari, setelah 10 hari telur dibersihkan dan dicuci.

c. Pembuatan ekstrak jahe dan kayu secang

- Ekstrak Jahe

Jahe yang akan dibuat ekstrak adalah jahe merah. Jahe terlebih dahulu dibersihkan dari kotoran dan dicuci menggunakan air bersih. Kemudian dipotong-potong kecil, dan jahe diblender dengan ditambahkan air panas untuk mendapatkan ekstraknya (terhomogenisasi). Untuk konsentrasi jahe yang akan dibuat adalah $75 \%$ (b/v) yaitu 750 gram jahe/1000 $\mathrm{ml}$ air, kemudian jahe yang sudah homogenisasi disaring hingga menghasilkan ekstrak jahe dan ditambahkan etanol $70 \%$ sehingga menghasilkan ekstrak jahe.

- Ekstrak Secang

Bahan yang digunakan adalah kayu secang yang diekstrak dengan air panas dengan konsentrasi 3\% ( 300 gram teh/10 liter air) dengan cara direbus selama 20 menit dengan suhu $70^{\circ} \mathrm{C}$.

d. Perendaman telur asin

Telur yang sudah mengalami pengasinan kemudian direndam menggunakan ekstrak jahe dan kayu secang selama 5 hari di dalam wadah / stoples.

e. Perebusan telur asin

Telur asin yang sudah direndam menggunakan ekstrak jahe dan secang kemudian direbus selama 15 menit dihitung setelah air rebusan mendidih.

Telur asin hasil penelitian Dilakukan uji kadar lemak dan kadar protein pada telur asin hasil penelitian.

\section{HASIL DAN PEMBAHASAN}

Inovasi Produk Telur Asin Sehat Rendah Lemak dengan menggunakan Telur itik dipilih dari telur yang segar (umur telur kurang dari 5 hari) dengan bentuk normal (oval) dan warna relatif sama (hijau kebiruan). Telur yang telah bersih dan kerabang utuh selanjutnya dilakukan candling, yaitu pengamatan bagian dalam telur/internal untuk melihat kondisi dan keadaan internal. Perendaman dengan larutan garam dan bata merah dengan menggunakan adonan garam dan bata merah dengan perbandingan 1:2, kemudian telur dipilih dan dicuci hingga bersih dan dibalut dengan adonan bata merah. Susun telur yang telah dibalut dalam ember selama 10 hari, setelah 10 hari telur dibersihkan dan dicuci. Kemudian 
dilanjutkan dengan Pembuatan ekstrak jahe dan kayu secang.. Ekstrak jahe dengan menggunakan jahe merah. Jahe terlebih dahulu dibersihkan dari kotoran dan dicuci menggunakan air bersih. Kemudian dipotong-potong kecil, dan jahe diblender dengan ditambahkan air panas untuk mendapatkan ekstraknya (terhomogenisasi). Untuk konsentrasi jahe adalah 75\% (b/v) yaitu 750gram jahe/1000 ml air, kemudian jahe yang sudah homogenisasi disaring hingga menghasilkan ekstrak jahe dan ditambahkan etanol 70\% sehingga menghasilkan ekstrak jahe. Selanjutnya Ekstrak Secang disiapkan dengan menggunakan kayu secang yang diekstrak dengan air panas dengan konsentrasi 3\% ( 300 gram teh/10 liter air) dengan cara direbus selama 20 menit dengan suhu $70^{\circ} \mathrm{C}$. Perendaman telur asin. Telur yang sudah mengalami pengasinan kemudian direndam menggunakan ekstrak jahe dan kayu secang selama 5 hari di dalam wadah / stoples. Perebusan telur asin. Telur asin yang sudah direndam menggunakan ekstrak jahe dan secang kemudian direbus selama 15 menit dihitung setelah air rebusan mendidih.

1. Hasil Analisis kadar lemak kuning telur pada telur asin hasil penelitian

Hasil Analisis Lab menunjukkan bahwa interaksi yang ada pada penambahan ekstrak jahe (Zingiber Officinale) dan ekstrak secang terhadap kadar lemak pada telur asin dapat dilihat pada tabel1. Kadar lemak kuningtelur pada telur asin berikut ini:

Tabel 1. Kadar Lemak kuning telur pada telur asin

\section{Kadar Lemak}

\begin{tabular}{lrrr}
\hline \multicolumn{1}{c}{ ID Sampel } & Berat lemak & Berat sampel & Kadar lemak \\
\hline Sebelum perlakuan & $0,34 \mathrm{~g}$ & 2 & $17,00 \%$ \\
Setelah perlakuan & $0,25 \mathrm{~g}$ & 2 & $12,50 \%$ \\
\hline
\end{tabular}

Dari tabel di atas dapat terlihat bahwa total kadar lemak yang terdapat dari telur asin setelah perlakuan mengalami penurunan sebanyak $0,34 \mathrm{~g}-0,25 \mathrm{~g}=0,09 \mathrm{gram}(4,5 \%)$. Hal ini disebabkan karena bahwa penambahan ekstrak jahe (Zingiber Officinale) dan ekstrak secang dapat menurun kadar lemak sebesar $(0,09 \mathrm{~g})$ atau $(4,5 \%)$. Hal ini berarti bahwa penambahan ekstrak jahe dan ekstrak secang dengan konsentrasi tinggi dapat memperkecil kadar lemak kuning telur asin. Hal ini disebabkan oleh adanya senyawa gingerol dan shogaol dari jahe dan senyawa asam galat serta tanin dari kayu secang bersifat sebagai anti bakteri dan astringent atau menciutkan dinding usus yang rusak karena asam/ bakteri. Kadar tanin ekstrak kayu secang dlperoleh dengan perebusan selama 20 menit adalah $0,137 \%$ (Winarti dan Nanan, 2005). Rebusan kayu secang dapat menurunkan pertumbuhan bakteri coli. Hasil penelitian Rochmah et al. fenol yang berperan sebagai anti oksidan sehingga semakin tinggi konsentrasi yang diberikan, maka semakin rendah kadar lemak telur asin, dengan adanya anti oksidan maka reaksi dapat dihambat, sehingga pembentukan senyawa aldehid, keton dan asam lemak bebas dapat dihambat. Hal ini sesuai dengan pendapat yang menyatakan bahwa anti oksidan dapat memberikan atom hydrogen secara cepat keradikal lipida dan atom mengubahnya kebentuk yang lebih stabil, sehingga anti oksidan dapat menghentikan reaksi berantai pada radikal bebas dari lemak yang teroksidasi (Ardiansyah, 2009). Zat warna dalam ekstrak kayu secang memberikan perubahan terhadap warna telur asin menjadi kuning tua. Hal tersebut dapat mempengaruhi organoleptik daging cincang (Rina et al. 2012), sedang hasil penelitian Rusdi et al. (2005) terhadap efek ekstrak kayu secang menunjukan bahwa ekstrak kayu secang mempunyai kemampuan anti oksidan sangat nyata paling baik dari pada vitamin $\mathrm{C}$ maupun vitamin $\mathrm{E}$,

Kandungan lemak terdapat dalam semua bahan makanan dan minuman. Pada dasarnya, semua lemak itu baik karena lemak dibutuhkan untuk menjaga kelangsungan hidup manusia. 
Fungsi lemak dalam tubuh manusia, lemak dibagi menjadi dua kelompok yaitu: lemak struktural dan lemak fungsional. Lemak struktural adalah bagian dari dinding sel. Sedangkan, lemak fungsional dapat berupa hormon steroid, prostaglandin, dan timbunan lemak yang dapat dipakai sebagai cadangan energi. Pada dasarnya, lemak makanan (dietary fat) memiliki fungsi untuk menyediakan energi jangka panjang, memberikan rasa kenyang setelah makan, membantu pembuatan hormon, membentuk bagian otak dan sistem saraf, membentuk membran sel untuk setiap sel di dalam tubuh, mengangkut vitamin $A, D, E$, dan $K$ ke seluruh tubuh, membantu mengatur suhu tubuh, serta menyediakan dua asam lemak esensial (seperti asam linoleat dan asam linolenat) yang tidak bisa dibuat sendiri oleh tubuh manusia. Berbagai penelitian menunjukkan hubungan erat antara jumlah konsumsi lemak dan timbulnya penyakit jantung koroner. Lemak jenuh dapat meningkatkan kejadian penyakit jantung koroner, sedangkan lemak tidak jenuh akan menurunkan kejadian penyakit jantung koroner. Konsumsi lemak tidak jenuh tunggal akan menurunkan gejala penyakit jantung koroner seperti pada penduduk di daerah Mediterania.

\section{Kadar protein pada telur asin}

Hasil Analisis Lab menunjukkan bahwa interaksi yang ada pada penambahan ekstrak jahe (Zingiber Officinale) dan ekstrak secang terhadap kadar protein pada telur asin dapat dilihat pada tabel 2. berikut ini :

Tabel 2. Kadar protein pada telur asin

\begin{tabular}{crrrrrrrr}
\hline Nama sampel & Berat sampel & \multicolumn{1}{c}{$\mathbf{V}_{\mathbf{1}}$} & $\mathbf{V}_{\mathbf{0}}$ & $\mathbf{N ~ H C l}$ & $\mathbf{K}$ & $\mathbf{f K}$ & $\mathbf{f P}$ & Kadar \\
\hline Sebelum perlakuan & 0,53 & 7 & 0,4 & 0,01 & 0,014 & 6,25 & 20 & $21,79 \%$ \\
Setelah perlakuan & 0,52 & 8,2 & 0,4 & 0,01 & 0,014 & 6,25 & 20 & $26,25 \%$ \\
\hline
\end{tabular}

Dari tabel di atas dapat terlihat bahwa total kadar protein yang terdapat dari telur asin setelah perlakuan mengalami peningkatan dari $21,79 \%$ meningkat menjadi $26,25 \%$. Peningkatan protein pada telur asin hasil penelitian adalh sebesar $(4,46 \%)$. Hal ini disebabkan karena bahwa penambahan ekstrak jahe (Zingiber Officinale) dan ekstrak secang dapat menaikkan kadar protein sebesar $(4,46 \%)$. Hal ini berarti bahwa penambahan ekstrak jahe dan ekstrak secang dengan konsentrasi tinggi dapat menaikkan kadar protein telur asin. Hal ini disebabkan oleh adanya senyawa gingerol dan shogaol dari jahe dan senyawa asam galat serta tanin dari kayu secang bersifat sebagai anti bakteri dan astringent atau menciutkan dinding usus yang rusak karena asam/bakteri. Kadar tanin ekstrak kayu secang dlperoleh dengan perebusan selama 20 menit adalah 0,137\% (Winarti dan Nanan, 2005). Rebusan kayu secang dapat menurunkan pertumbuhan bakteri coli. Hasil penelitian Rochmah et al. fenol yang berperan sebagai anti oksidan sehingga semakin tinggi konsentrasi yang diberikan, maka semakin rendah kadar protein telur asin, dengan adanya anti oksidan maka reaksi dapat dihambat, sehingga pembentukan senyawa aldehid, keton dan asam lemak bebas dapat dihambat. Hal ini sesuai dengan pendapat yang menyatakan bahwa anti oksidan dapat memberikan atom hydrogen secara cepat keradikal lipida dan atom mengubahnya kebentuk yang lebih stabil, sehingga anti oksidan dapat menghentikan reaksi berantai pada radikal bebas dari lemak yang teroksidasi (Ardiansyah, 2009). Zat warna dalam ekstrak kayu secang memberikan perubahan terhadap warna telur asin menjadi kuning tua. Hal tersebut dapat mempengaruhi organoleptik telur asin (Rina et al. 2012), sedang hasil penelitian Rusdi et al. (2005) terhadap efek ekstrak kayu secang menunjukan bahwa ekstrak kayu secang mempunyai kemampuan anti oksidan sangat nyata paling baik dari pada vitamin $\mathrm{C}$ maupun vitamin $\mathrm{E}$.

Telur itik merupakan salah satu sumber gizi yang baik. Menurunnya kadar lemak hasil penelitian sebesar $(4,5 \%)$ dan meningkatnya kadar protein telur asin sebesar $(4,46 \%)$ dianjurkan konsumen dapat 
mengkonsumsi telur itik dalam jumlah normal, yaitu 1-2 butir per hari, akan memberikan sumbangan gizi yang sangat berarti bagi kesehatan tubuh. Kadar air pada telur itik lebih rendah dari telur ayam. Hal itu berarti telur itik lebih kental bila dibandingkan telur ayam. Kadar energy pada telur itik tersebut sebagian besar berasal dari kandungan lemak dan proteinnya. Protein telur itik terdiri atas ovalbumin (putih telur) dan ovavitelin (kuning telur). mengandung asam amino esensial yang sangat diperlukan tubuh. Fungsi protein yang utama adalah untuk pertumbuhan tubuh, penggantian sel yang rusak, serta pembentukan enzim dan hormon. Telur itik mengandung vitamin A. Vitamin A pada telur itik berperan penting dalam mengatur fungsi penglihatan dan menjaga kesehatan mata, membantu pertumbuhan dan meningkatkan system imunitas (kekebalan tubuh). Lemak pada telur itik terdiri atas trigliserida (lemak netral), fosfolipida (umumnya berupa lesitin), dan kolestrol. Kandungan kolestrol pada telur itik juga lebih besar daripada telur ayam. Trigliserida dan fosfolipida dapat menjadi sumber energy bagi tubuh, sedangkan koletrol berperan untuk pembentukan vitamin D, hormon seks, dan komponen penyusun otak. Kebutuhan tubuh akan kolestrol adalah $1.100 \mathrm{mg}$ per hari. Kadar kolestrol total di dalam tubuh disarankan tidak melebihi 200 $\mathrm{mg} / 100 \mathrm{ml}$ darah. Dengan demikian tidak ada larangan mengonsumsi telur itik, sepanjang tidak dilakukan dalam jumlah yang berlebihan. Konsumsi telur itik dalam jumlah normal yaitu 1-2 butir per hari akan memberikan sumbangan gizi yang sangat berarti bagi kesehatan tubuh.

Untuk itu dapat direkomendasikan bahwa telur asin hasil penelitian lebih sehat untuk dapat dikonsumsi ditinjau dari kadar lemak dan protein yang dihasilkan total kadar lemak yang terdapat dari telur asin setelah perlakuan mengalami penurunan sebanyak 0,09 gram (4,5\%). Dan kadar protein pada telur asin hasil penelitian mengalami peningkatan dari $21,79 \%$ menjadi $26,25 \%$.

\section{KESIMPULAN}

Total kadar lemak yang terdapat dari telur asin setelah perlakuan mengalami penurunan sebanyak $0,34 \mathrm{~g}-0,25 \mathrm{~g}=0,09 \mathrm{gram}(4,5 \%)$. Dan kadar protein pada telur asin hasil penelitian mengalami peningkatan dari $21,79 \%$ menjadi $26,25 \%$. Untuk itu dapat direkomendasikan bahwa telur asin hasil penelitian lebih sehat untuk dapat dikonsumsi ditinjau dari kadar lemak dan protein yang dihasilkan.

\section{SARAN}

Disarankan penelitian ini dapat dilanjutkan dengan mengkaji kadar kolesterol, lemak pada telur asin dengan metode perendaman jahe dan kayu secang.

\section{REFERENSI}

AOAC. 2006. Official Methods of Analytical of The Association of Official Analytical Chemist.

Washington, DC:AOAC.

Astawan, M. 2008. Telur asin, aman dan penuh gizi. . Diakses pada 17/10/2005. $11.56 \mathrm{am}$.

Belitz, H. D and W, Grosch. 1999. Food chemistry. Second Edition. Springer. Berlin.

Buckle, K. A., R. A. Edwards, G. H. Fleet dan M. Wootton. 2007. Ilmu Pangan, Terjemah: H. Purnomo dan Adiono. Universitas Indonesia, Jakarta .

Farmer, L. J. 1999. Poultry meat flavour. In Poultry Science Symposium Series, vol. 25.International Publishing.

Hadiwiyoto, S. 1983. Hasil-Hasil Olahan Susu, Ikan, Daging dan Telur. Liberty, Yogyakarta.

Hudaya, S dan S. Dradjat. 1980. Dasar-dasar Pengawetan I. Departemen Pendidikan dan

Kebudayaan. Direktorat Pendidikan Menengah Kejuruan, Jakarta.

IPTEK. 2006. Proses pembuatan telur asin. . 2008a. Teh hijau.. 
- 2008b. Telur dan kolesterol.

—. 2008c. Takut makan telur sama dengan fobia kolesterol. . 2009a. Abu (Analisis kimia

Winarno, F. G dan S. Koswara. 2002. Telur : Komposisi, Penanganan dan Pengolahannya. M-Brio Press. Bogor. 